\title{
Finding Inspiration: Sharing Practice and Developing Authentic Multimedia Artifacts for Supervision of Undergraduate Research in Irish higher education
}

\author{
Roisin Donnelly \\ Technological University Dublin, roisin.donnelly@tudublin.ie \\ Claire McAvinia \\ Technological University Dublin, claire.mcavinia@tudublin.ie \\ Claire McDonnell \\ Technological University Dublin, claire.mcdonnell@tudublin.ie
}

Follow this and additional works at: https://arrow.tudublin.ie/ltcbk

Part of the Education Commons

\section{Recommended Citation \\ Donnelly, R., McAvinia, C., \& McDonnell, C. (2020). Finding Inspiration: Sharing Practice and Developing Authentic OER Multimedia Artefacts for Supervision of Undergraduate Research. In N.H. Hensel \& P. Blessinger (Eds.) International Perspectives on Undergraduate Research: Policy and Practice. Palgrave Macmillan.}

This Book Chapter is brought to you for free and open access by the Learning Teaching \& Assessment at ARROW@TU Dublin. It has been accepted for inclusion in Books/Book Chapters by an authorized administrator of ARROW@TU Dublin. For more information, please contact arrow.admin@tudublin.ie, aisling.coyne@tudublin.ie,gerard.connolly@tudublin.ie.

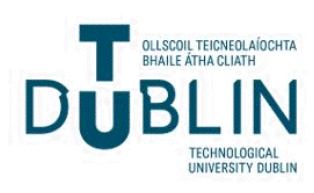


Finding Inspiration: Sharing Practice and Developing Authentic Multimedia Artifacts for Supervision of Undergraduate Research in Irish higher education Roísín Donnelly, Claire McAvinia, Claire McDonnell

TU Dublin, Ireland 


\section{Author Biographies}

Dr. Roisin Donnelly is Head of Learning Development for the College of Business in the new TU Dublin. This role sees her supporting the College in achieving impact and excellence in teaching and learning through partnership and program provision, promoting enhanced [e]learning strategies and Business Education communities of practice. This builds on her previous positions as Lecturer, Program Chair/Coordinator, Academic Developer for 18 years and as sectoral Project Manager for the initial national implementation of the Professional Development Framework for teachers in Irish higher education. She is a member of the national Professional Development (PD) Advisory Group established to shape how the National Forum for the Enhancement of Teaching and Learning achieves sectoral strategic objectives in relation to PD. She is a fellow of the UK Staff and Educational Development Association (FSEDA), a fellow of the Higher Education Academy (FHEA), and co-editor of the Irish Journal of Academic Practice. (150 words)

Dr. Claire McDonnell is Assistant Head at the School of Chemical and Pharmaceutical Sciences in TU Dublin. Her interests include facilitating learner transition to higher education and the application of technology to support student learning and collaboration. She has implemented several approaches to embed research and enquiry skills in the curriculum, including context and problem based learning and community engaged learning. She spent a 3 year secondment with the TU Dublin Learning, Teaching and Technology Centre from 2013-16 where she was program coordinator for their MA in Higher Education. Claire is a founding member of the Chemistry Education Research Team at TU Dublin, which won a DELTA award from the Irish National Forum for the Enhancement of Teaching and Learning in 2018. (121 words)

Dr. Claire McAvinia is an Academic Developer at the Learning, Teaching and Technology Centre (LTTC) in TU Dublin. She is currently LTTC Programmes Chair and lectures on the Centre's accredited postgraduate programs and modules in learning and teaching, and e-learning. Her interests are in academic development, digital literacies, curriculum design and open education. Claire is engaged in supervision of students in Masters and Doctoral programs. She has published on a range of topics in e-learning and academic development, and in 2016 completed a book based on her doctoral research, Online Learning and its Users: Lessons for Higher Education. Claire is a Fellow of the UK Staff and Educational Development Association (SEDA) and the UK Higher Education Academy. Together with Dr Roisin Donnelly and Dr Kevin O'Rourke, she co-edits the Irish Journal of Academic Practice (IJAP). (135 words) 


\begin{abstract}
Supervision is a specialist academic practice that can be learnt through the experience of the practice of supervision itself. However, increasingly, supervisors can find inspiration from each other in structured, supported, collaborative professional development. This Chapter evaluates the perceived impact on faculty and student learning of sharing inspirational practices and creating multimedia artifacts which formed the assessment of an accredited postgraduate module entitled 'Supervising Undergraduate Dissertations and Projects' at a Technological University in Ireland. A range of themes are explored in the Chapter including the increasing demand for this form of professional development for academics; the importance of a peer learning approach for providing inspiration and sharing of practice; the design and development of multimedia artifacts for undergraduate supervision practice and the national context within which this work is situated. Participants were surveyed to explore how they now approach supervision and how they disseminated their multimedia artifact in undergraduate supervision. Findings indicate increased levels of confidence, clearer communication in the supervision conversation, greater emphasis on guiding rather than leading the student, and improved feedback processes.
\end{abstract}

Keywords: Artifacts; Faculty Support; Multimedia; Open Educational Resources (OER); Professional Development; Supervision practice; Undergraduate Research. 


\section{Introduction}

Good supervision is essential in ensuring successful outcomes for undergraduate research students, yet few new supervisors receive training for this role (Roberts \& Seaman, 2017; Healey \& Jenkins, 2018). In the context of Irish higher education, there have been calls for investment by higher education institutions (HEIs) into provision of suitable supervisor professional development opportunities. Since the late 1990s, the research landscape in Ireland has developed very significantly, underpinned by the recognition that talented people are at the heart of any national innovation system. Significant investment has resulted in Ireland ascending in international rankings of research capacity (HEA, 2017). This is a positive development in postgraduate supervision. However, the majority of faculty in Irish HEIs have undergraduate supervision roles without the professional development (PD) opportunities that exist to support masters and doctorate level supervision. Hanratty, Higgs and Tan (2011, p.37) have observed that 'academic staff who are attempting to initiate change in undergraduate teaching and learning strategies are often working in isolation within centers where postgraduate disciplinary research dominates the agenda.' Rowley and Slack (2004) have argued for a proactive approach to supervisor development. This study reports on a module that has been developed as such a proactive form of PD for undergraduate supervisors in Irish higher education.

The authors are faculty developers and academics in a new Technological University in Ireland, TU Dublin. In common with others (Roberts \& Seaman, 2018), we have found plentiful research into the supervision of PhD students and some on Masters projects, but much less to draw on for supervisors at undergraduate level. Over the last five years, there have been a number of publications in the area of undergraduate research mentorship. The term applied to the student - faculty member relationship in Ireland, and also in the UK and Australia, is ‘supervision' and mentoring can extend beyond a professional supervision relationship to a 
personal one (Larson et al., 2018). Even so, these recent publications have been a welcome addition which can be drawn from. In Ireland, as is the case in the UK, all honors degrees usually incorporate a capstone research project. The module at the heart of this study was designed to support both novice and more experienced undergraduate supervisors. It has been running since

2015 and is entitled 'Supervising Undergraduate Dissertations and Projects' ${ }^{1}$. The module forms part of an accredited postgraduate program for faculty - the MSc in Education offered in TU Dublin.

In this Chapter, we present the specific details of the module and the national context in which it is situated. We then present an evaluative study of the impact of the module exploring how sharing supervision practice as well as the production of a multimedia resource have helped supervisors of undergraduate research find inspiration from each other. We discuss participants' perceptions of what makes excellent undergraduate research, the implications of this for their practice, and the place of the module in shaping that practice. We conclude by identifying the benefits of the module and aspects of supervisors’ PD that can be further developed and supported.

\section{National Context and Rationale for PD in Undergraduate Supervision}

Nationally and internationally, undergraduate research has become more prominent in recent years. In Ireland, research is an important element of most undergraduate degree programs across the disciplines. The National Framework of Qualifications (2003) sets guidelines for the definition of undergraduate program learning outcomes at the honors degree level which point towards the inclusion of undergraduate research projects and dissertations. These requirements include (NQAI, 2003, p.17):

\footnotetext{
${ }^{1}$ http://www.dit.ie/aadlt/lttc/academicdevelopment/postgradcpd/supervisingugdissertationsprojects/
} 
- Detailed knowledge and understanding in one or more specialized areas, some of it at the current boundaries of the field(s).

- Demonstrate mastery of a complex and specialized area of skills and tools; use and modify advanced skills and tools to conduct closely guided research, professional or advanced technical activity.

- Use advanced skills to conduct research, or advanced technical or professional activity, accepting accountability for all related decision making; transfer and apply diagnostic and creative skills in a range of contexts.

- Act effectively under guidance in a peer relationship with qualified practitioners; lead multiple, complex and heterogeneous groups.

The Irish National Framework of Qualifications has been approved as being compatible with the Qualifications Framework for the European Higher Education Area (Quality and Qualifications Ireland, 2006) which means that it is consistent with the European bachelor, master and doctorate cycles (Bologna Working Group, 2005).

Undergraduate research is disseminated locally in institutions through events and exhibitions, but also nationally through conferences and seminars. Examples are the Science Undergraduate Research Conference and the All Ireland Conference of Undergraduate Research. ${ }^{2}$ Similar conferences and events take place in the UK, and have been observed with interest. Faculty active in such events in the UK have visited TU Dublin to speak about their work, including contributing inputs to our module on topics that have broad resonance, such as

\footnotetext{
${ }^{2}$ http://sure-network.ie/conference/ https://www.ul.ie/ctl/events/all-ireland-conference-undergraduate-research-aicur
} 
strategies for good practice throughout the supervision lifecycle, and linking teaching and research throughout the curriculum.

The module we developed is the first of its kind in the Irish HE sector. Since its inception, there have been participants from across the HE sector in Ireland, although the majority have been based in Dublin or the surrounding areas. As such, it can be regarded as representative of the issues facing UG supervisors nationally. This national audience includes supervisors new to their role, from across the disciplines, as well as more experienced supervisors who wish to share and expand their knowledge and experience in the UG research domain. Participants joining together in their learning in this module from institutions across the sector means that a sharing of different institutional regulations and practices, roles, expectations and responsibilities of the UG supervisor takes place. It is especially insightful for participants from many different contexts to have a space where they can collectively acknowledge the challenges of UG supervision and the accompanying assessment process. The module supports this range of UG supervisors from across the disciplines and institutions to reflect on their supervision practice for both pedagogic and professional development reasons, whilst cultivating scholarly exchange by encouraging them to share and critique dialogues about UG supervision.

Colleagues in two other HEIs have recently validated modules relating to undergraduate supervision and there are plans to commence these shortly. Also, a Digital Badge for supervision of postgraduate research has recently been developed by the National Forum for the Enhancement of Teaching and Learning, aligned with Ireland’s National Framework for Professional Development (2016), and this may be used by faculty with wider-ranging supervision responsibilities. Provision in some institutions allows for supervisors of undergraduate research to join modules or workshops intended for supervisors of postgraduate 
research, but this approach does not seem to be widespread. However, the argument for tailored development activities for supervisors of undergraduate research emerges clearly from the literature, as we explore further in the next section.

\section{Demand for Professional Development for Undergraduate Supervisors}

A review of the literature in faculty development and undergraduate research highlights a series of calls for professional development around a number of themes. Educational literature acknowledges the value for academics inquiring into and critically reflecting on their professional practice. Wisker (2012) has drawn attention to the need for supervisor professional development in the light of diversity, change and demand from one subject, one institution and one supervisor to another. She argues that both supervisors and institutions need to focus on supervisory developmental needs and practices. We are in agreement that the role is now more visible, and needs clarification and development for faculty, recognizing differences from one discipline to another, and one supervisor to another. As Wisker points out, many faculty perform this role but there are few opportunities to reflect on, develop or share good practice with others. This line of thinking informed the approach we undertook to the development of the PD module.

There have been more recent calls for supervisors who have been trained in mentorship (The Guardian, 2017; Moore \& Felten, 2018). Additionally, supervisors of undergraduate research face challenges in a context where the ethos of support and well-being in relation to students is arguably at an all-time high (Wynaden, Wichmann \& Murray, 2013). We sought to recognize the potential value of peer support to build confidence, as this has previously been identified as important in academic development (Boud, 1999; Warhurst, 2006) and building professional confidence. 
There have been extensive guidelines produced to support supervisors and students in research, particularly at postgraduate level, nationally and internationally (Lee, 2012; Wisker, 2012). A new 'Supervising Postgraduate Research', SEDA course is on offer in UK institutions for new PG supervisors, which runs twice a year over two intensive days, supported by online activities and a portfolio. In addition, the Research Supervision Recognition Programme is a professional development toolkit which includes the sector approved 'Good Supervisory Practice’ Framework and offers a route to recognition specifically for research supervision, from the UK Council for Graduate Education (2019). Comprehensive work by the National Academy for Integration of Research, Teaching and Learning (NAIRTL, 2012) in Ireland had a particular focus on developing a framework to provide training and support for academic supervisors of research postgraduate students, including workshops, short courses and other initiatives. Although NAIRTL is no longer active, it previously worked with Irish higher education institutions to develop, implement and advance effective research-informed teaching and learning practices to enhance the student learning experience at undergraduate (Hanratty et al., 2011) and postgraduate levels. To this end, NAIRTL has initiated a wide range of events and activities that support stronger links between research and teaching (NAIRTL, 2011).

In Vereijken’s (2017) study on novice supervisors’ practices, analysis revealed four kinds of dilemmas which may influence research supervision practices, namely questions regarding regulation, student needs in relation to supervision, the student-supervisor relationship and supervisors' professional identity. Further afield, the scholars' conversations in Larson, Partridge, Walkington, Wuetherick and Moore (2018) of key terms, concepts and initiatives in mentored undergraduate research and inquiry in different international contexts was helpful in shaping our own local practice. 
In terms of the topics that PD needs to explore for supervisors, a focus on the supervisorsupervisee relationship remains paramount. This relationship can be awkward and confusing, and sometimes uncomfortable and challenging (Grant, Schofield \& Crawford, 2012). In Irish HE, there is not a formal body that guides staff in best practice in undergraduate supervision, and many programs that do exist for faculty are optional. The professional relationship between supervisor and student has received significant consideration in the literature. Rowley (2000) argues that the underlying philosophy is that supervision is a partnership between student and supervisor. Wisker (2012) encourages supervisors to reflect on and enhance their research supervision practice with a diversity of students on a variety of research projects. The studentsupervisor relationship and style of supervision has also been previously investigated at undergraduate level with Hammick and Acker (1998) in particular exploring knowledge flow and power dynamics. As part of this valuable relationship, feedback has been identified as playing an important role. A study by Baker, Cluett, Ireland, Reading and Rourke (2014) reported that $88 \%$ of students reported peer supervision to be helpful, with themes being 'support and sharing', and 'progress and moving forward'.

Of particular relevance to our PD module, disciplinary perspectives in supervision have also been the source of research in previous years. Zydney, Bennett, Shahid, and Bauer (2002) analyzed the perceptions of 155 science and engineering faculty in a university with an extensive undergraduate research program. Faculty thought the undergraduate research experience provided important educational benefits to the students, in agreement with results from an alumni survey. Faculty who supervised undergraduates for a longer period of time and who modified their research program to accommodate undergraduates perceived a greater enhancement of important cognitive and personal skills. Within the discipline of social science, Todd, Smith and 
Bannister (2006) investigated the experiences and perceptions of faculty supervising final year undergraduates, specifically their perspectives of the supervision process, the different approaches taken to supervision and the challenges they face in supporting students through the dissertation journey.

While there are professional development opportunities for UG supervisors in Ireland and elsewhere, we have not encountered any that support the supervisor in designing, implementing and evaluating an OER artifact for their own supervisory practice. Claims for innovation are present in the literature in the form of collaborative and group-based supervision and there are instances of technology being used in UG supervision practice such as audio at the conclusion of supervisory meetings with recordings of students summarizing the discussion (Voelkel, Mello and Varga-Atkins, 2018). However, supporting UG supervisors to consider their own supervisory style and the context of their practice before what for many for them is a new endeavor and places them outside their comfort zone in using a variety of multimedia tools is, we feel, a novel and engaging approach in this field.

\section{Connecting with Open Educational Practices}

An additional interest shared by the authors has been in emergent debates around open educational practices (OEPs) in higher education. We were keen to recognize these developments through the design of this module, and in the interests of developing and supporting supervisors of undergraduate research. Bates (2014) and Couros (2016) discuss the characteristics of the $21^{\text {st }}$ century educator in terms of openness and collaboration in practice, and creating, sharing and curating open educational resources (OERs) for teaching. In the context of this module, openness in teaching can be regarded as reflecting and discussing practice in the open, rather than in traditionally isolated or individual modes (Cronin \& 
MacLaren, 2018). In the creation and sharing of a multimedia resource, we encouraged participants to be open in terms of best practices with their peers and students. There was potential to share these resources more widely as OERs in their own right (Wiley, 2015).

\section{The Supervising Undergraduate Dissertations and Projects Module}

The module was designed and validated in 2015, taking an expressly collaborative approach in its delivery and calling on practitioners to create resources which could support them in their work as supervisors. Table 1 shows the alignment of module learning outcomes, teaching and learning methods, and assessment strategy. Constructive alignment (Biggs, 2003) was the theoretical underpinning of the outcomes-based module, with coherence between assessment, teaching and learning strategies and the intended learning outcomes. It was important that activities were designed which enabled participants to learn how to demonstrate achievement at the highest level described by the outcomes.

The module has been offered in the second semester of each academic year but one since 2015. 40 participants have now successfully completed it. 10 participants have been students of our MA in Higher Education, working as faculty in TU Dublin or other HEIs across Ireland and in wide-ranging disciplinary contexts. These students had the option to take the module as an elective. The remainder have participated in the module on a stand-alone basis for continuing professional development, and have come from across the Colleges of TU Dublin:

- Arts and Tourism (13)

- Business (seven)

- Engineering and Built Environment (eight)

- Sciences and Health (two) 


\section{INSERT TABLE x.1: Constructive Alignment within the PD Module}

\begin{tabular}{|c|c|c|}
\hline Learning outcomes & $\begin{array}{l}\text { Teaching and Learning } \\
\text { Activities }\end{array}$ & Summative Assessment \\
\hline $\begin{array}{l}\text { Critically analyze what constitutes } \\
\text { a productive undergraduate } \\
\text { research learning environment }\end{array}$ & \multirow{2}{*}{$\begin{array}{l}\text { - Review of 'Rethinking Final } \\
\text { Year Projects and } \\
\text { Dissertations: Creative } \\
\text { Honors and Capstone } \\
\text { Projects' resource by Mick } \\
\text { Healey - note thoughts on the } \\
\text { Introduction and select one of } \\
\text { the case studies and discuss } \\
\text { how it could be applied to } \\
\text { own practice. }\end{array}$} & \multirow{4}{*}{$\begin{array}{l}\text { A reflective account, supported } \\
\text { with reference to the literature, of } \\
\text { the design and development of the } \\
\text { resource, to include the context } \\
\text { and underlying rationale as well as } \\
\text { plans for implementation and } \\
\text { consideration of the potential for } \\
\text { wider application and } \\
\text { dissemination. }\end{array}$} \\
\hline $\begin{array}{l}\text { Explore conceptions of } \\
\text { undergraduate research and } \\
\text { supervisory practice, } \\
\text { contextualized by critical } \\
\text { engagement with salient and } \\
\text { emergent issues in their own } \\
\text { discipline }\end{array}$ & & \\
\hline $\begin{array}{l}\text { Critically review the literature on } \\
\text { the scholarship of undergraduate } \\
\text { supervision pedagogy and of } \\
\text { relevant policy issues in } \\
\text { undergraduate research } \\
\text { supervision }\end{array}$ & $\begin{array}{l}\text { Select one of the three } \\
\text { provided journal articles and } \\
\text { then summarize and critically } \\
\text { analyze it in the online } \\
\text { discussion board in the VLE. }\end{array}$ & \\
\hline \multicolumn{2}{|l|}{$\begin{array}{l}\text { Evaluate their efficacy and } \\
\text { competency in undergraduate } \\
\text { research supervision }\end{array}$} & \\
\hline $\begin{array}{l}\text { Discuss institutional requirements } \\
\text { and procedures for undergraduate } \\
\text { supervisors and research students, } \\
\text { including ethics requirements }\end{array}$ & $\begin{array}{l}\text { Develop a question that could } \\
\text { be sent in advance to the guest } \\
\text { contributing in the final week. } \\
\text { - Participate in discussions with } \\
\text { guest contributors. }\end{array}$ & \multirow{3}{*}{$\begin{array}{l}\text { Multimedia resource or resources } \\
\text { (e.g. videos, screencasts with } \\
\text { audio, word press site, infographic } \\
\text { etc.) that address two of the four } \\
\text { supervision themes provided in } \\
\text { relation to own context. }\end{array}$} \\
\hline $\begin{array}{l}\text { Evaluate and apply suitable } \\
\text { undergraduate supervisory } \\
\text { strategies and procedures for their } \\
\text { own context }\end{array}$ & $\begin{array}{l}\text { - As a Learning Set of } 4 \text { people, } \\
\text { develop an overview of } \\
\text { Getting Started / First Steps in } \\
\text { the Undergraduate } \\
\text { Supervision Process using a } \\
\text { mind map in electronic } \\
\text { format. }\end{array}$ & \\
\hline $\begin{array}{l}\text { Devise strategies for interactional } \\
\text { and communication skills e.g. } \\
\text { negotiation, giving feedback, } \\
\text { which is supportive and } \\
\text { challenging }\end{array}$ & $\begin{array}{l}\text { Peer review session in final } \\
\text { week - each participant speaks } \\
\text { for } 5 \text { minutes about their } \\
\text { resource and their peers and } \\
\text { module leaders complete a } \\
\text { short peer feedback form. }\end{array}$ & \\
\hline
\end{tabular}


The module was divided into five weekly workshops, focusing on specific themes: getting started with supervision; the identity and role of the UG supervisor; enhancing UG supervision practices to ensure impact (including the most effective ways of working and interacting with UG students in their dissertation); and disseminating good practice with input from other supervisors in the institution and beyond. As each cohort has a proportion of new supervisors, it was useful to explore self-perceptions of the novice supervisor's experience and attributes, issues affecting the novice supervisor's role, and supports and resources available for novice supervisors. One of the sessions took place in a computer room to allow participants to work on their OERs while tutors were present.

In terms of topics addressed in the module, a study in the Irish higher education context (Donnelly, Dallat \& Fitzmaurice, 2013) revealed that supervisors identified the main student challenges in completing an undergraduate dissertation as pressure of work, managing time effectively and having the confidence needed for success. Deciding on a topic that was 'do-able' as well as knowing precisely what was expected at this level were also highlighted. The timing of the dissertation could also pose challenges, not least when undertaken by students with other modules in one semester. These areas were included as topics for exploration in the current curriculum for the PD module. Other themes explored are the culture of undergraduate research, supporting a program team approach to supervision, clarifying supervisor roles and student responsibilities, supporting the undergraduate dissertation process, exploring common issues in supervision, and assessing dissertations. When unpacking initial learning issues with the participants, topics that have emerged are GDPR impact on research [this is the EU General Data Protection Regulation, which was implemented in 2018 and is an important change in data privacy regulation], having a unified and agreed approach within their department or school to 
process (time management, research methods and clear procedures) and product of supervision (exploring opportunities for other alternate approaches to a dissertation/capstone project); how to manage new supervisors in the department; supervising across programs (what can be shared) and achieving consistency in feedback to students.

A key dimension of the module is the design and development of an authentic multimedia artifact by each participant to support their own supervision practice and framed around the themes explored in the module. To accompany this, participants are required to write a reflective and scholarly piece (Table x.1). The multimedia resource can then be used as a resource by both students and academic faculty. Learners will have this additional support and guidance to help them as the resources deal with some of the common questions, concerns and practical issues that undergraduate students come across when completing their dissertation or final year project. The resource can also provide useful information for other faculty who are supervising undergraduate dissertations.

The aim is not to provide a set of definitive answers about supervising a dissertation or final year project; instead participants will recognize that there are many ways in which the 'journey' through the supervision process can be completed. The resources can draw on a combination of the experiences of the dissertation supervisors on the module, academic research into faculty experiences of supervision, and examples of good practice.

Within the module workshops, input was invited from several guests who gave their perspectives on several approaches to undergraduate research implemented in our institution. The apprentice model was discussed as was a group research project. Also incorporated was an input on community-based research. This approach is applied in our university with the support of the Students Learning with Communities office. They have developed very clear guidance on 
what the roles and responsibilities of students and supervisors are in this context (Students

Learning With Communities, 2019).

Table x.2 and Figures 1-5 give some examples of the range of multimedia artifacts in which participants chose to develop their most pressing supervision topics.

INSERT TABLE x.2 HERE: Authentic Multimedia Artifacts on Undergraduate

\section{Supervision}

\begin{tabular}{|l|l|l|l|}
\hline & $\begin{array}{l}\text { Type of } \\
\text { Multimedia } \\
\text { Resource }\end{array}$ & Supervision Topic & Supervision Content \\
\hline $\begin{array}{l}2014-15 \\
\text { cohort }\end{array}$ & Video & $\begin{array}{l}\text { Final Year Group } \\
\text { Project Support }\end{array}$ & $\begin{array}{l}\text { Support for Game Development students } \\
\text { during their final year group project, } \\
\text { addresses common problems that arise such } \\
\text { as group conflict and the expectation that } \\
\text { responsibility lies with students. }\end{array}$ \\
\hline $\begin{array}{l}\text { 2015-16 } \\
\text { cohort }\end{array}$ & Screencast & $\begin{array}{l}\text { Checklist for } \\
\text { submitting a group } \\
\text { report } \\
\text { (first years) }\end{array}$ & $\begin{array}{l}\text { Assessment requirements for an enquiry- } \\
\text { based group project report including Gantt } \\
\text { charts. }\end{array}$ \\
\hline $\begin{array}{l}2017-18 \\
\text { cohort }\end{array}$ & Infographic & $\begin{array}{l}\text { Integrated learning } \\
\text { portfolios }\end{array}$ & $\begin{array}{l}\text { Structured guidance for students } \\
\text { researching and compiling evidence of } \\
\text { learning in a social care program }\end{array}$ \\
\hline $\begin{array}{l}\text { 2018-19 } \\
\text { cohort }\end{array}$ & Small-scale website & $\begin{array}{l}\text { Academic writing and } \\
\text { referencing }\end{array}$ & $\begin{array}{l}\text { Tailored to the participant's discipline, a } \\
\text { curated set of resources addressing writing } \\
\text { and referencing from other well-regarded } \\
\text { websites, with commentary. }\end{array}$ \\
\hline
\end{tabular}


INSERT Figure x.1 HERE: Video resource for final year students by Camila D'Bastiani

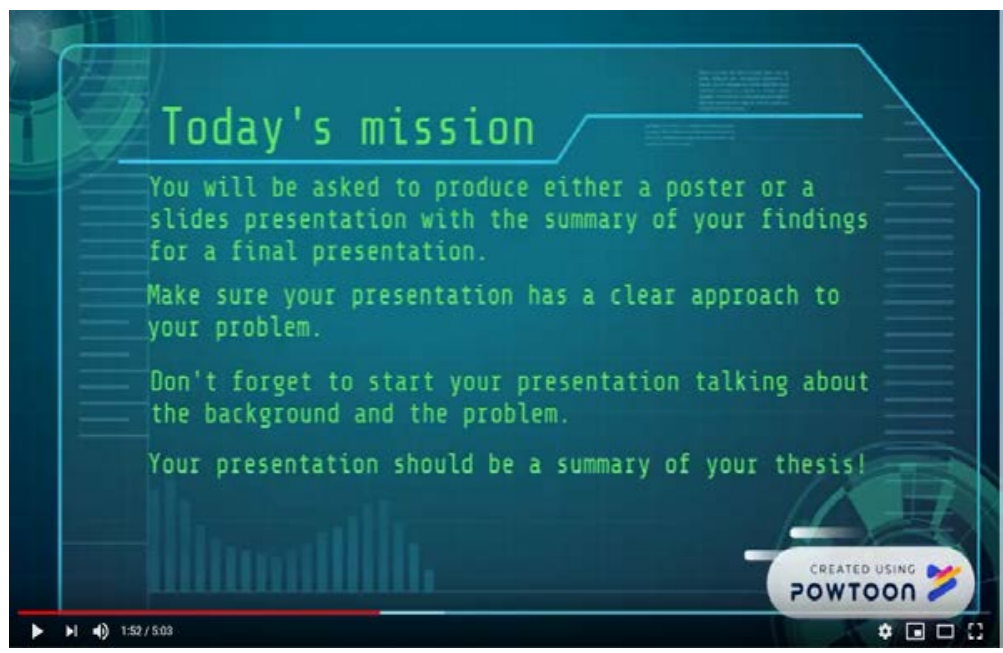

INSERT Figure x.2 HERE: Mindmap to support Supervisors and Students by Jennifer Byrne

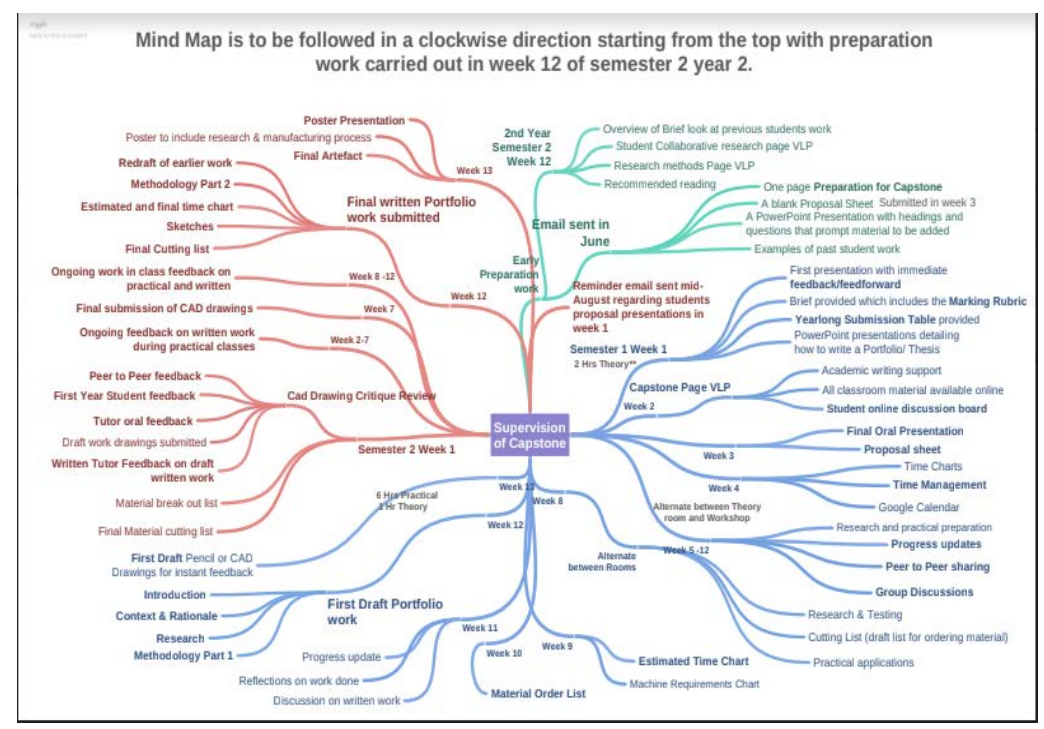

INSERT Figure x.3 HERE: Infographic to support Supervisors and Students by Martina

\section{Ozonyia}




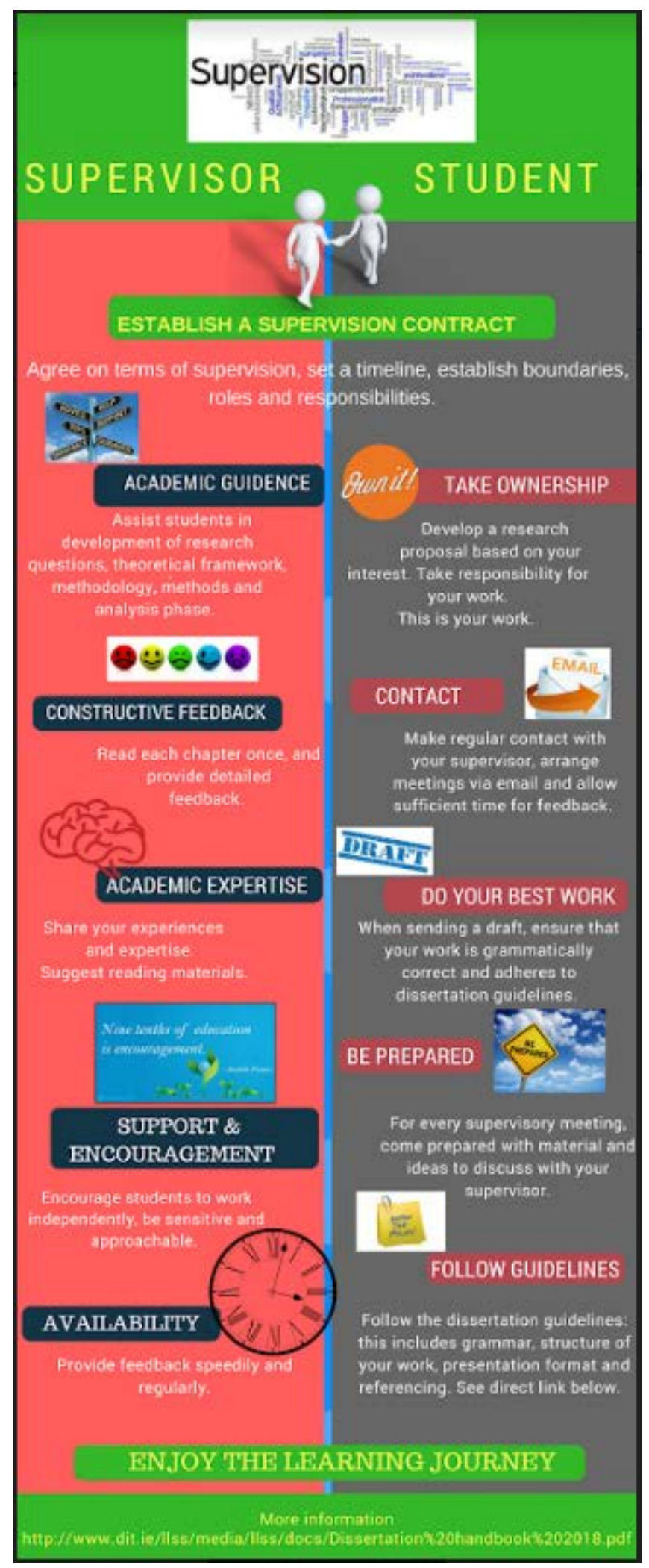


INSERT Figure x.4 HERE: Video resource to support students by Michelle Bermingham

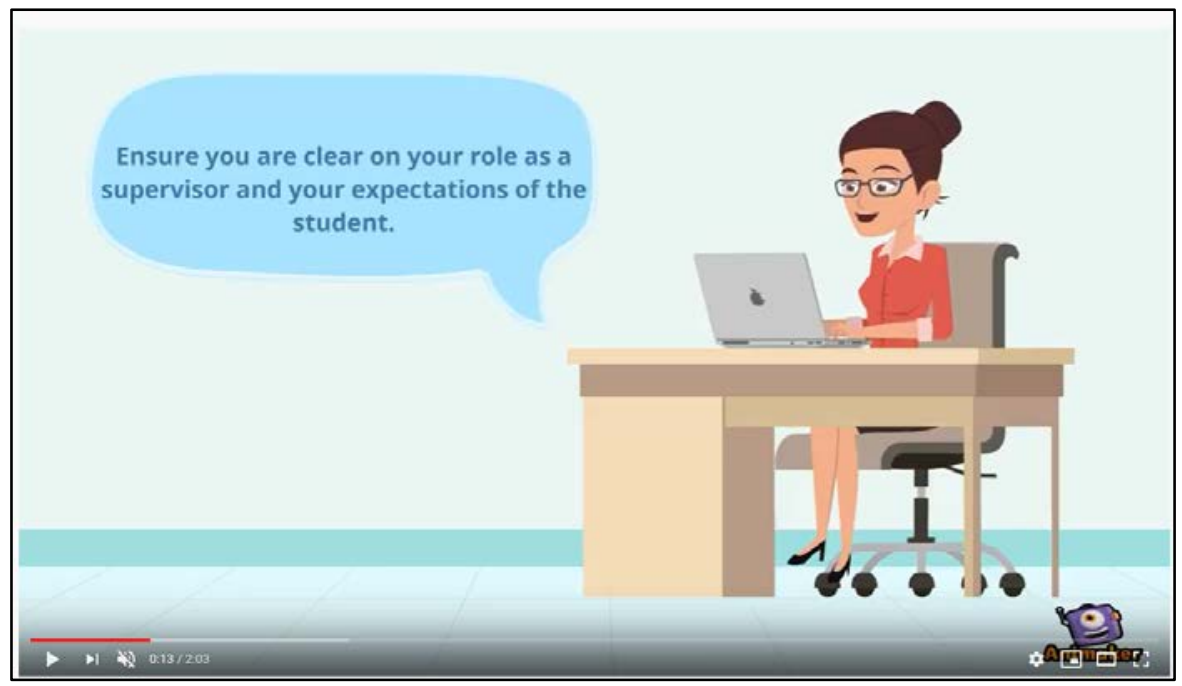

INSERT Figure x.5 HERE: Website to support students by Niall Minto (2018)

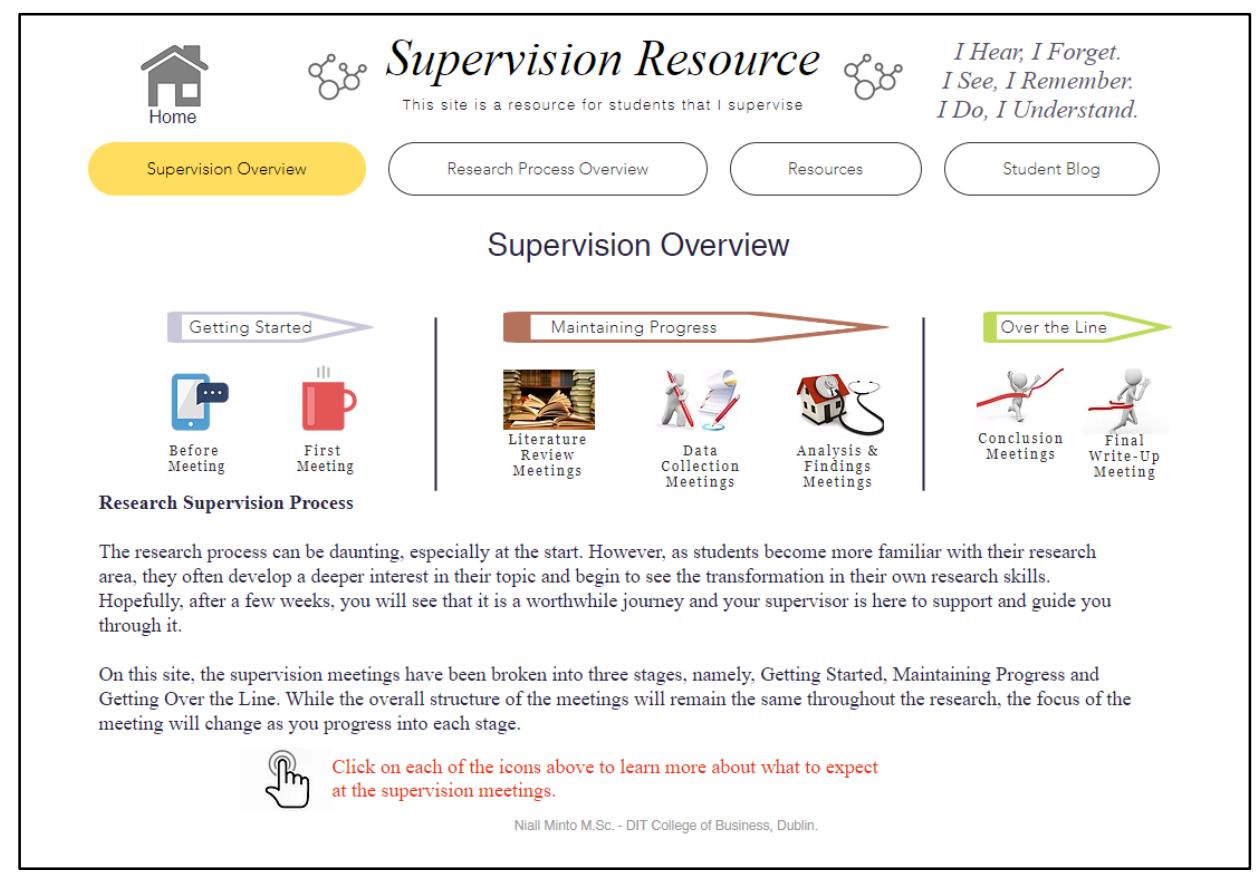




\section{Methodology and Methods}

We designed a short and focused evaluation of the module to address the following research question:

What is the perceived impact of sharing practices and creating multimedia artifacts in a professional development undergraduate supervision module in the context of the Irish higher education sector?

All 40 graduates of the module were surveyed using an online questionnaire (Appendix A). The questions were developed through engagement with the literature on best practice in UG Supervision as well as our own expertise in delivering professional development in this area for a number of years.

There were three sections to the questionnaire, with the first asking closed questions to establish the profile of the participant - their discipline, current engagement with UG supervision, and the nature of the UG supervision taking place in their School/Institution. The second section focused on the UG Supervision module in relation to meeting the needs of UG supervisors in Ireland as a form of current professional development. It asked questions to establish participant motivations for undertaking the module as well as on the different areas of supervision that were considered important to each participant. Each were via provision of a 5 point Likert scale, followed by an open-ended question. The Likert scale was based on establishing importance in each instance it was used: the scale went from not important; somewhat; important; very; and not applicable.

Two open-ended questions were included to ascertain participant perceptions/understanding of what makes a good supervisor before they took the module, and after they had completed it. Further open questions were asked to build a picture of what makes an excellent undergraduate dissertation or research project, and what the supervisor can do to 
support production of that excellent work. A question on the impact of the module was included on whether participants had continued researching resources or literature about undergraduate supervision. The third section of the online questionnaire asked open questions on participants' prior skillset with developing multimedia resources generally and in relation to supporting UG supervision, and a Likert scale was included to establish the extent of the impact that the multimedia artifact has had on students and colleagues in supporting the supervision process.

The Centre in which the module is offered has an existing approved protocol to address ethical issues in research relating to the evaluation of its programs, and we conducted the evaluation in line with this approved protocol. 17 people responded to the questionnaire, five from 2018-19, seven from 2017-18 and four from 2015-16. All respondents were from TU Dublin - six respondents came from the College of Arts and Tourism, two from the College of Sciences and Health, five from the College of Business and three from the College of Engineering and the Built Environment. We present findings first in relation to participants' experiences of the module overall, and then in relation to the development of their multimedia resources.

\section{Presentation and Discussion of Findings}

13 respondents were currently supervising UG dissertations, and two were not. From a logistical perspective, supervision of undergraduate research was undertaken as follows: 14 participants had supervision hours timetabled as part of their teaching schedule for meeting individual students for the duration of the supervision process, six participants had received submissions of draft work of the UG research project at different points in the semester in order to provide formative feedback to the students, three gave email advice and updates to their students, two provided online materials in the Webcourses/Brightspace VLE, and two used 
tutorials. The remainder was a mix of one participant who had hours included in their teaching timetable for group supervision, one having dedicated time in lectures or laboratory/practical classes e.g. for project management, and one using online submissions.

\section{Rationale for Module Participation}

Looking at the strongest reasons/motivations for doing the module: wanting to better support students in the supervision process was considered very important (12); closely followed by finding out about best practice in undergraduate research supervision (11); knowing how to deal with challenges in the supervision of undergraduate research (eight); meeting colleagues also engaged in undergraduate supervision (seven); and clarification of the supervisor's role in relation to research (six). Learning to develop a multimedia resource to support supervision was considered important/somewhat important by a total of 11 participants.

Participants were given the opportunity to share other reasons for undertaking the module and nine responded. There was a mix of wanting to learn from local practice, compare their own practices with colleagues, and explore the role of the supervisor in a supportive environment. Two were beginning to supervise dissertations, having had no previous experience in supervision, and three others wished to develop a consistent and fair supervision process, be trained how to supervise students properly and obtain clarification on standard practice and procedures around supervision. For one participant, this module formed part of the postgraduate qualification they were undertaking (MA in Higher Education).

\section{Comparison of Attributes of a Good Supervisor Before and After the Module}

It was interesting to note a set of attributes or characteristics of good practice in supervision that participants had before they undertook the module, and after it was completed. Figure x.6 shows the combined similarities that appeared before and after the accredited 
professional development module, with advice based on analysis of the data shown in blue at the end of each section. These findings can be considered in the context to the work of Shanahan et al. (2015) who identified ten characteristics of effective undergraduate research mentorship. Seven of their characteristics are similar to the attributes below that emerged in this study. The remaining three do not feature in our findings and they relate to development of student mentoring skills, building a research community among students and supporting students in networking activities.

INSERT FIGURE X.6 HERE: Findings on good practice in undergraduate supervision 


\section{Strive for clarity throughout the supervision process}

Consider how best to ensure clear communication and support of the student Need to be prepared and help students fully understand key steps of research process: knowing common pitfalls [scope; research question; importance of a robust lit review; understanding core tenets of methodology]

Agree what communication will be in place for the duration of the project

\section{Explore mentoring relationship}

Relationship based on interest and and enthusiasm for topic

Need to show compassion, be approachable, have patience; ensure students are invested to do good work rather than 'chasing' them

Be a person who adapts their style to suit the needs of the students Listen to students, challenge them

\section{Delineation of expectations}

Provide a clearer boundary about supervision to ensure students know that the work is their own and for them to take full responsibility

Try to ensure "contract" is in place and understood

Be a guide, rather than a leader, so as to allow the student to experience 'real' research (ups and downs)

\section{Adhere to Disciplinary Norms}

Provide guidance about subject discipline and thesis process

Important for supervisor to have discipline expertise and project management skills

\section{Supervisor Skills}

Understand the theoretical basis of supervision

Explain what time management means in this context; Agree when student work should be submitted for timely feedback

Provide clear advice on procedures \& practices in the research process

\section{Provide Feedback at 'dissertation landing points'}

Consider how to best generate and provide excellent feedback that will have an impact on student work

Need to be honest with feedback

Give specific information positively and ask the student questions 


\section{Perceptions of What Makes Excellent Undergraduate Research and the Role of the Supervisor to Support Excellent Work}

Eight participants shared their perceptions of excellent undergraduate research, characterizing it in the following ways: "engaged and interested" (Participant 5); "literature review is linked to context and on to findings" (Participant 7); "something unique and different" (Participant 10); "succinct presentation of topic with a clear research question supported in the literature” (Participant 17); has a clear “topic, methodology, theory and excellent writing” (Participant 11); "that the student can demonstrate what they have learned from the project" (Participant 14); “clear, concise work that answers the question” (Participant 16); "good critical analysis of primary data linked with secondary data" (Participant 17), and "a story from start to finish that adds to the research already there” (Participant 16).

The supervisor could contribute by: "making sure the student was focused on key tasks" (Participant 7); supporting the student's decision-making on the research topic (Participant 9); "guiding the student toward defining the aim/objective at the outset" (Participant 10); keeping in contact with the student and keeping the dissertation in line with the research questions (Participant 16); identifying the research question “early on” (Participant 17) so that "an appropriate literature review would be undertaken, as many students spend most of their time on the literature review without having identified a good research question” (Participant 17). It can be useful to point supervisors to existing resources for supporting students to develop their research skills such as Willison and O’Regan’s (2007) Research Skill Development Framework which can be used to both chart and monitor students' research skill development. Conducting a research skills audit as part of the first supervisory meeting is an area that is discussed in the current module, and does not seem to form part of the existing practice of the participants. 


\section{Perceived Module Impact on Practice}

Since completing the module, eleven participants have continued researching resources or literature about undergraduate supervision, and three indicated that they have not. Advice summarized from the participants’ feedback on what they think should happen after the module included:

- Mentoring of Supervisors: “Any new supervisors should shadow a qualified supervisor so they can learn from them” (Participant 7).

- Needs of New Supervisors: "Staff should not undertake any supervision until this course is completed. [If] I was given the chance to design the course I would include more practical application for new supervisors e.g. how to complete a good literature review understanding research methodologies and methods - common mistakes with quant/qual research” (Participant 7).

- Reassurance/Endurance: “I found the module supported many of my current practices and that was reassuring. I also realized how I have to keep working at the process” (Participant 9).

- Network of Supervisors: "Forming networks with other supervisors” (Participant 10); “I have recommended it to many colleagues” (Participant 14).

\section{Creation and Use of the Multimedia Resource}

When asked if they had been using multimedia resources, technologies or apps to support supervision of undergraduate research before attending the module, 12 of the 17 respondents commented. Of these, five said that they had not been using such resources. One mentioned the resource created during the module. The remaining six were using a variety of resources: two had websites guiding students through supervision, one mentioned creation of 
YouTube clips for students, one used research papers, and one had a mix of material on the virtual learning environment including a separate Pinterest board for research in their module.

Before participating in the module, four people had created their own multimedia resources for students but ten others who responded had not. We asked participants in the research to comment on the creation and use of the multimedia resource by responding to a series of statements in a Likert-type question. We mixed positive and less positive statements about the process, to avoid leading the participants. 14 people responded.

Most agreed or strongly agreed that it had been straightforward to create the multimedia resource, but two disagreed. Since the earlier iterations of the module, we have introduced a specific workshop to support the multimedia resource and this may have helped the more recent participants. Ten of the participants disagreed with the statement that it was difficult to think of a rationale for the resource, suggesting that most could think of a clear reason for developing it. Opinions were a little more mixed on the usefulness of the resource, nine agreeing or strongly agreeing that it had been useful and five disagreeing or not expressing a firm view on this. These findings reflect existing research on faculty use of open educational resources in Ireland (National Forum, 2015) which show a similar pattern of somewhat uneven use of online resources, and caution amongst faculty around creating, using and re-using resources.

Most of the participants said they would be happy to share the resource with colleagues in their department or School, with just one out of 14 indicating they were not sure about this question. However, responses to sharing beyond the institution were more mixed: 11 people said they would agree they would be happy to do this, three were less certain. Again, this may reflect a more general wariness around sharing educational resources in the Irish higher education sector (National Forum, 2015). This is something we would like to address further through the module 
since the sharing of practice has been of central importance to participants, and they have indicated the value of this. This in turn would support greater openness in practice and pedagogy with the creation and sharing of resources (Cronin \& MacLaren, 2018). The early iterations of the module emphasized copyright issues and also used the feedback process to comment on specific issues for each resource, something we have continued to do in the most recent cohorts.

We presented a statement suggesting that the multimedia resource had benefited students undertaking undergraduate research. It could be anticipated that this might be difficult to answer unless participants had evaluated the use of the resource by their students. The responses appeared to indicate this with eight people agreeing or strongly agreeing, but one choosing 'not applicable' and five neither agreeing nor disagreeing with the statement. It was perhaps also difficult for them to comment on the extent to which the resource benefited their colleagues supervising undergraduate students: five agreed or agreed strongly with this, five neither agreed nor disagreed, with two saying it was not applicable to them and two disagreeing. Within the module, we have not given space to discussion of evaluation of the resource and therefore it is likely that participants are not seeking feedback from their students about the value of using the resources. When asked to respond to a statement about gathering formal feedback about the resource, just three people said that they had done this. This is an area that we could address much further in future, and it may also be appropriate to incorporate students' contributions to further resources in keeping with a students-as-partners approach to curriculum (Healey, Flint \& Harrington, 2014).

Finally, participants were asked to respond to a statement about whether they would like to create further resources for their students. Seven people said that they would, but six did not commit to a view on this and one person disagreed with the statement. This is perhaps a little 
disappointing since the module offered scope to open up this possibility and perhaps support the creation of suites of resources within the different disciplines. With an opportunity to explore this further, we will ask participants whether they used their multimedia skills elsewhere on completion of the module in other professional projects. This could be an aspect of practice that we seek to develop more fully in future iterations. Later, when asked if they had created further

resources, five people indicated that they had. These included ongoing development of a website, creation of a separate set of resources and guides, finding existing third party materials and sharing them online, and formalizing processes through creation of forms to support supervision. Two participants commented that they did not have time to create further resources.

It appears that a follow-up workshop for all participants in the module next year would be warranted, to facilitate participants in making changes before they might choose to release their resources publicly. They could also be given advice as to how to evaluate the resources being used, pitch new OERs and potentially collaborate with each other in producing these.

\section{Macro Level Issues}

From the findings, it is interesting to consider the bigger picture issues discussed in this current book. As we are based in a newly established Technological University in Ireland, the first of its kind nationally, the scope of undergraduate inquiry and research needs to be more visible and supported. There are currently some inter-institutional undergraduate research celebration days (http://sure-network.ie/about/; https://www.ul.ie/ctl/students/all-irelandconference-undergraduate-research-aicur), and this can be built upon as can students-as-partners in research (faculty and students co-authoring papers and co-presenting at regional and national conferences). Development of enquiry and research skills earlier within the curriculum is also an important consideration (Healey, Lannin, Stibble, \& Derounin 2013). 


\section{Conclusions and Recommendations}

In this Chapter we have presented the arguments for greater professional development opportunities for faculty supervising undergraduate research, contextualizing this within the Irish higher education sector. We described and explained our professional development module which is available to faculty undertaking supervision of undergraduate research at a new Technological University, TU Dublin as well as faculty based in other Irish HEIs. Our evaluation of this module showed that participants had explored and articulated the characteristics of good, even excellent, undergraduate research. They perceived a positive impact on their practice from having had the opportunity to do this through the module by talking with their peers and sharing practice. They identified a range of pathways towards successful completion of the research dissertation or project, and this has been reflected in the wide-ranging multimedia resources developed over the past four years. While at this stage it might be somewhat premature to talk of the module overtly in terms of OEPs, and the resources as OERs, this valuable perspective offers us several directions in which to develop the work in future. We suggest that there needs to be growing recognition of the importance of undergraduate research, and that it should be celebrated in Ireland more widely in the ways we have seen happening internationally. This would in turn raise the standing of good undergraduate supervision, and recognize the efforts and supports discussed by colleagues in this short module. We will continue to develop and evaluate this module over the longer term, potentially through the development of mentoring and networks of support for new supervisors within the disciplines. We would also like to encourage greater sharing of the multimedia resources given the participants' time and effort invested in producing these. Our findings throughout this research have repeatedly shown the value and importance of collegial discussion in building confidence and resilience amongst faculty meeting the needs of larger and ever more diverse groups of students (Higher Education Authority, 2018). 
We conclude by encouraging colleagues nationally and internationally to address support for supervisors through appropriate PD, and particularly through allowing critical conversations amongst colleagues to take place in supportive spaces. 


\section{References}

Baker, M., Cluett, E., Ireland, L., Reading, S., \& Rourke, S. (2014). Supervising undergraduate research: A collective approach utilising group-work and peer support. Nurse Education Today, 34(4), 637-642.

Bates, S. (2014). Anatomy of 21st century educators. Retrieved from: https://www.slideshare.net/EdPER_talks/the-anatomy-of-the-21st-century-educator

Biggs. J. (2003). Teaching for Quality Learning at University - What the Student Does. 2nd Edition. Buckingham: SRHE/Open University Press.

Bologna Working Group (2005). A Framework for Qualifications of the European Higher Education Area. Bologna Working Group Report on Qualifications Frameworks, Danish Ministry of Science, Technology and Innovation.

Boud, D. (1999). Situating academic development in professional work: Using peer learning. The International Journal for Academic Development, 4(1), 3-10.

Couros, G. (2016). 10 essential characteristics of a 21st century educator. Connected Principals Sharing. Learning. Leading. Retrieved from: http://connectedprincipals.com/archives/13542

Cronin, C. \& MacLaren, I. (2018). Conceptualising OEP: A review of theoretical and empirical literature in Open Educational Practices. Open Praxis, 10(2), 127-143. Retrieved from https://files.eric.ed.gov/fulltext/EJ1177676.pdf

Donnelly, R., Dallat, J., \& Fitzmaurice, M. (Eds.) (2013). Supervising and Writing a Good Undergraduate Dissertation. Oak Park, Ill: Bentham Science Publishers.

Grant, J., Schofield, M.J., \& Crawford, S. (2012). Managing Difficulties in Supervision: Supervisors’ Perspectives. Journal of Counseling Psychology, 59(4), 528-541.

Hammick M., \& Acker, S. (1998). Undergraduate research supervision: A gender analysis. Studies in Higher Education, 23(3), 335-347.

Hanratty, O., Higgs, B., \& Tan, E. (2011). Irish perspectives on undergraduate research. Council on Undergraduate Research Quarterly, 31(4), 33-42.

Healey, M., Lannin, L., Stibble, A., \& Derounin, J. (2013). Developing and enhancing undergraduate final-year projects and dissertations. Retrieved from 
https://www.heacademy.ac.uk/knowledge-hub/developing-and-enhancingundergraduate-final-year-projects-and-dissertations

Healey, M., Flint, A. \& Harrington, K. (2014). Engagement through partnership: students as partners in learning and teaching in higher education. York: Higher Education Academy.

Healey, M., \& Jenkins, A. (2018). The role of academic developers in embedding high-impact undergraduate research and inquiry in mainstream higher education: twenty years' reflection. International Journal for Academic Development, 23(1), 52-64.

Higher Education Authority (2017). National Framework for Doctoral Education. Dublin: HEA.

Higher Education Authority (2018). Key Facts and Figures: Higher Education 2017/8. Dublin: HEA. Retrieved from https://hea.ie/assets/uploads/2019/01/Higher-EducationAuthority-Key-Facts-Figures-2017-18.pdf

Larson, S., Partridge, L., Walkington, H., Wuetherick, B., \& Moore, J.L. (2018). An international conversation about mentored undergraduate research and inquiry and academic development. International Journal for Academic Development, 23(1), 6-14.

Lee, A. (2012). Successful Research Supervision: Advising Students Doing Research. London: Routledge.

Moore, J.L., \& Felten, P. (2018). Academic development in support of mentored undergraduate research and inquiry. International Journal for Academic Development, 23(1), 1-5.

NAIRTL (2011). NAIRTL Grants Initiative: Evaluation of Impact. Cork: NAIRTL.

NAIRTL (2012). Developing an institutional framework for supporting supervisors of research students: A Practical Guide. Cork: NAIRTL.

National Forum for the Enhancement of Teaching and Learning in Higher Education. (2015). Learning Resources and Open Access in Higher Education Institutions in Ireland. Retrieved from https://www.teachingandlearning.ie/publication/learning-resources-andopen-access-in-higher-education-institutions-in-ireland/

National Forum for the Enhancement of Teaching and Learning in Higher Education (2016). The National Professional Development Framework. Retrieved from 
https://www.teachingandlearning.ie/publication/national-professional-developmentframework-for-all-staff-who-teach-in-higher-education/

National Qualifications Authority of Ireland (NQAI). (2003). National Framework of Qualifications. Dublin: NQAI.

Quality and Qualifications Ireland (2006). Verification of Compatibility of Irish National Framework of Qualifications with the Framework for Qualifications of the European Higher Education Area. Retrieved from https://www.qqi.ie/Publications/Publications/Verification\%20of\%20Compatibility\%20o f\%20NFQ\%20with\%20QF\%20EHEA\%20220609.pdf

Roberts, L.D., \& Seaman, K. (2017). Good undergraduate dissertation supervision: Perspectives of supervisors and dissertation coordinators. IJAD, 23(1), 28-40.

Roberts, L.D., \& Seaman, K. (2018). Students' experiences of undergraduate dissertation supervision. Frontiers in Education, 3, article 109.

Rowley, J. (2000). Thirteen tips for successful supervision of undergraduate dissertations. Educational Developments, 1(1), 14-15.

Rowley, J., \& Slack, F. (2004). What is the future for undergraduate dissertations? Education and Training, 46(4), 176-181.

Shanahan, J. O., Ackley-Holbrook, E., Hall, E., Stewart, K., \& Walkington, H. (2015). Ten salient practices of undergraduate research mentors: A review of the literature. Mentoring \& Tutoring: Partnership in Learning, 23(5), 359-376.

Students Learning With Communities (2019). Guidelines on roles for students community partners and lecturers. Retrieved from http://www.dit.ie/media/ace/slwc/worddocuments/TU\%20Dublin\%20guidelines\%20on \%20roles\%20for\%20students,\%20supervisors\%20and\%20community\%20partners.pdf

The Guardian, Academics Anonymous (2017). Not all PhD supervisors are natural mentors some need training. The Guardian, 28 July 2017. Retrieved from:

https://www.theguardian.com/higher-education-network/2017/jul/28/not-all-phdsupervisors-are-natural-mentors-some-need-training?CMP=new_1194

Todd, M.J., Smith, K., \& Bannister, P. (2006). Supervising a social science undergraduate dissertation: staff experiences and perceptions. Teaching in Higher Education, 11(2), 161-173. 
UK Council for Graduate Education (2019). The Good Supervisory Practice Framework. Retrieved from: https://supervision.ukcge.ac.uk/good-supervisory-practice-framework/

Vereijken, M.W. (2017). Novice supervisors' practices and dilemmatic space in supervision of student research projects. Teaching in Higher Education, 23(4).

Voelkel, S., Mello, L.V., \& Varga-Atkin, T. (2018). Supporting students during their undergraduate research projects using audio recordings. Innovations in Education and Teaching International, 55(4), 433-440.

Warhurst, R. P. (2006). “We Really Felt Part of Something”: Participatory learning among peers within a university teaching-development community of practice. International Journal for Academic Development, 11(2), 111-122.

Wiley, D. (2015). Defining the "Open” in Open Content and Open Educational Resources. Retrieved from: http://opencontent.org/definition/

Willison, J., \& O'Regan, K. (2007). Commonly known, commonly not known, totally unknown: A framework for students becoming researchers. Higher Education Research and Development, 26(4), 393-409.

Wisker, G. (2012). The Good Supervisor: Supervising Postgraduate and Undergraduate Research for Doctoral Theses and Dissertations. London: Palgrave Macmillan.

Wynaden, D., Wichmann, H., \& Murray, S. (2013). A synopsis of the mental health concerns of university students: Results of a text-based online survey from one Australian university. Higher Education Research \& Development, 32(5), 846-860.

Zydney, A.L., Bennett, J.S., Shahid, A., \& Bauer, K. (2002). Faculty Perspectives Regarding the Undergraduate Research Experience in Science and Engineering. Journal of Engineering Education, 91(3), 291-297. 
Appendix A: Evaluation Questionnaire

Section A: The Basics

In which year did you complete the Supervising Undergraduate Dissertations and Projects module? [Select from list of 2019, 2018, 2016, 2015]

In which College of the City Campus are you based? [Select from Sciences and Health, Business, Engineering and Built Environment, Arts and Tourism]

Are you currently engaged in supervising undergraduate research? [Select from Yes/No]

How is supervision of undergraduate research currently undertaken in your School? (please tick any applicable) [List included below]

- Supervision hours timetabled for individual students

- Supervision hours timetabled for group supervision

- Dedicated time in lectures or practicals e.g. for project management, work-in-progress, updates

- Email advice and updates

- Provision of online materials in Webcourses/Brightspace

- Submissions of draft work at different points in the semester

- Tutorials

- Using an online discussion board or forum

Section B: The Module

Were any of the following important in your decision to take the Supervising Undergraduate Dissertations and Projects module? [Likert Scale question using scale: not important - somewhat important - important - very important - not applicable]

- Clarification of the Supervisor's role in relation to research

- Finding out about best practice in undergraduate research supervision

- Learning to develop a multimedia resource to support supervision

- Meeting colleagues also engaged in undergraduate supervision

- Knowing how to deal with challenges in the supervision of undergraduate research

- Wanting to better support your students in the supervision process

Were there any other reasons to take the module? [open text response]

What did you think were the attributes of a good supervisor *before you took the module*? [open text response] 
What do you think are the attributes of a good supervisor *having completed the module*? [open text response]

Can you comment on what makes an excellent undergraduate dissertation or research project, and what the Supervisor can do to support production of that excellent work? [open text response]

Since completing the Supervising Undergraduate Dissertations and Projects module, have you continued researching resources or literature about undergraduate supervision? [Select Yes/No]

Section C: The Multimedia Resource

Can you give any examples of how you were using multimedia resources, technologies, or apps to support supervision of undergraduate research before you attended the Supervising Undergraduate Dissertations and Projects module? [open text response]

Had you ever created your own multimedia resource for your students before participating in the Supervising Undergraduate Dissertations and Projects module? [Select Yes/No]

Please indicate your responses to the following statements: [Likert Scale question using scale disagree strongly - disagree - neither agree nor disagree - agree - agree strongly - not applicable]

- I found it fairly straightforward to create the multimedia resource

- It was difficult to think of a rationale for the multimedia resource

- The multimedia resource has been useful in my supervision of undergraduate research

- I had a clear idea of a typical student in mind when I designed the multimedia resource

- I am happy to share the multimedia resource with colleagues in my department/School

- I would be happy to share my multimedia resource with any colleague internally or externally to the institution

- The multimedia resource has benefited the students undertaking undergraduate research

- The multimedia resource has benefited my colleagues supervising undergraduate students

- I have gathered formal feedback about the multimedia resource from my students and/or colleagues

- I would like to create more multimedia resources for my students from now on

Since completing the Supervising Undergraduate Dissertations and Projects module, have you produced other resources for your colleagues or students? [Select Yes/No]

Can you give any further details in relation to the previous question?

\section{Section D: Conclusion}

Do you have any further comments in relation to the module or the questions raised by this questionnaire? 